\title{
Simulated last glacial maximum D14Catm and the deep glacial ocean carbon reservoir
}

Article

Published Version

Creative Commons: Attribution 3.0 (CC-BY)

Open Access

Mariotti, V., Paillard, D., Roche, D.M., Bouttes, N. and Bopp, L. (2013) Simulated last glacial maximum D14Catm and the deep glacial ocean carbon reservoir. Radiocarbon, 55 (2-3). pp. 1595-1602. ISSN 0033-8222 doi: https://doi.org/10.2458/azu_js_rc.55.16295 Available at https://centaur.reading.ac.uk/37271/

It is advisable to refer to the publisher's version if you intend to cite from the work. See Guidance on citing.

Published version at: https://journals.uair.arizona.edu/index.php/radiocarbon/index

To link to this article DOI: http://dx.doi.org/10.2458/azu_js_rc.55.16295

Publisher: University of Arizona

All outputs in CentAUR are protected by Intellectual Property Rights law, including copyright law. Copyright and IPR is retained by the creators or other copyright holders. Terms and conditions for use of this material are defined in the End User Agreement.

www.reading.ac.uk/centaur 
Central Archive at the University of Reading

Reading's research outputs online 


\title{
SIMULATED LAST GLACIAL MAXIMUM $\Delta{ }^{14} \mathrm{C}_{\mathrm{atm}}$ AND THE DEEP GLACIAL OCEAN CARBON RESERVOIR
}

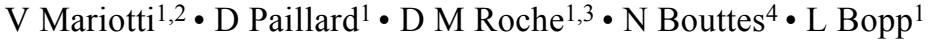

ABSTRACT. $\Delta^{14} \mathrm{C}_{\text {atm }}$ has been estimated as $420 \pm 80 \%$ (IntCa109) during the Last Glacial Maximum (LGM) compared to preindustrial times $(0 \%)$, but mechanisms explaining this difference are not yet resolved. $\Delta^{14} \mathrm{C}_{\mathrm{atm}}$ is a function of both cosmogenic production in the high atmosphere and of carbon cycling and partitioning in the Earth system. ${ }^{10} \mathrm{Be}-\mathrm{based}$ reconstructions show a contribution of the cosmogenic production term of only $200 \pm 200 \%$ in the LGM. The remaining $220 \%$ o have thus to be explained by changes in the carbon cycle. Recently, Bouttes et al. $(2010,2011)$ proposed to explain most of the difference in $\mathrm{pCO}_{2 \text { atm }}$ and $\delta^{13} \mathrm{C}$ between glacial and interglacial times as a result of brine-induced ocean stratification in the Southern Ocean. This mechanism involves the formation of very saline water masses that contribute to high carbon storage in the deep ocean. During glacial times, the sinking of brines is enhanced and more carbon is stored in the deep ocean, lowering $\mathrm{pCO}_{2 \mathrm{~atm}}$. Moreover, the sinking of brines induces increased stratification in the Southern Ocean, which keeps the deep ocean well isolated from the surface. Such an isolated ocean reservoir would be characterized by a low $\Delta^{14} \mathrm{C}$ signature. Evidence of such ${ }^{14} \mathrm{C}$-depleted deep waters during the LGM has recently been found in the Southern Ocean (Skinner et al. 2010). The degassing of this carbon with low $\Delta{ }^{14} \mathrm{C}$ would then reduce $\Delta^{14} \mathrm{C}_{\mathrm{atm}}$ throughout the deglaciation. We have further developed the CLIMBER-2 model to include a cosmogenic production of ${ }^{14} \mathrm{C}$ as well as an interactive atmospheric ${ }^{14} \mathrm{C}$ reservoir. We investigate the role of both the sinking of brine and cosmogenic production, alongside iron fertilization mechanisms, to explain changes in $\Delta^{14} \mathrm{C}_{\text {atm }}$ during the last deglaciation. In our simulations, not only is the sinking of brine mechanism consistent with past $\Delta{ }^{14} \mathrm{C}$ data, but it also explains most of the differences in $\mathrm{pCO}_{2 \mathrm{~atm}}$ and $\Delta{ }^{14} \mathrm{C}_{\mathrm{atm}}$ between the LGM and preindustrial times. Finally, this study represents the first time to our knowledge that a model experiment explains glacial-interglacial differences in $\mathrm{pCO}_{2 \mathrm{~atm}}, \delta^{13} \mathrm{C}$, and $\Delta^{14} \mathrm{C}$ together with a coherent LGM climate.
\end{abstract}

\section{INTRODUCTION}

Records of the last deglaciation present a very well documented time series of $\Delta^{14} \mathrm{C}_{\mathrm{atm}}$, from around $420 \pm 80 \%$ at the Last Glacial Maximum (LGM, defined here as 18-24 ka BP, following Mix et al. 2001 ) to $0 \%$ during the preindustrial period (Reimer et al. 2009). Variations in $\Delta{ }^{14} \mathrm{C}_{\mathrm{atm}}$ depend both on the cosmogenic production rate of ${ }^{14} \mathrm{C}$ in the upper atmosphere and on the exchange of ${ }^{14} \mathrm{C}$ between the atmosphere, the terrestrial biosphere, and the ocean. Both model and data studies have investigated the causes of these changes in $\Delta^{14} \mathrm{C}$ during the last deglaciation. Broecker and Barker (2007) do not exclude the possibility that ${ }^{14} \mathrm{C}$ production rate reconstructions could be underestimated during the glacial period, and thus that ${ }^{14} \mathrm{C}$ production only could explain LGM $\Delta^{14} \mathrm{C}$. In their studies based on geomagnetic field and ${ }^{10} \mathrm{Be}$ estimates, Muscheler et al. $(2004,2005)$ suggest that the production rate cannot explain the entire magnitude of the $\Delta^{14} \mathrm{C}_{\mathrm{atm}}$ change during last deglaciation, but that changes in the global carbon cycle are also needed. Different mechanisms have been proposed to study the role of the carbon cycle in the decreased $\Delta{ }^{14} \mathrm{C}_{\mathrm{atm}}$ during this period: a sudden interruption of deep water formation (Meissner et al. 2003); a resumption of ocean circulation (Köhler et al. 2005, 2006); a reduction in the biological pump caused by reduced iron fertilization (Köhler et al. 2005, 2006); an increase in Southern Ocean vertical mixing rates (Köhler et al. 2005; Tschumi et al. 2011); or a breakdown in Southern Ocean stratification (Köhler et al. 2005). The latter 2 mechanisms imply changes in the Southern Ocean ventilation but do not give any precise physical mechanism to explain such changes.

\footnotetext{
${ }^{1}$ Laboratoire des Sciences du Climat et de l'Environnement (LSCE/IPSL), CEA/CNRS-INSU/UVSQ, Gif-sur-Yvette Cedex, France.

${ }^{2}$ Corresponding author. Email: veronique.mariotti@1sce.ipsl.fr.

${ }^{3}$ Cluster Earth and Climate, Faculty of Earth and Life Sciences, Vrije Universiteit, Amsterdam, the Netherlands.

${ }^{4}$ NCAS-Climate, Department of Meteorology, University of Reading, Reading RG6 6BB, United Kingdom.
}

(C) 2013 by the Arizona Board of Regents on behalf of the University of Arizona

Proceedings of the 21st International Radiocarbon Conference edited by A J T Jull \& C Hatté

RADIOCARBON, Vol 55, Nr 2-3, 2013, p 1595-1602 


\section{VMariotti et al.}

Bouttes et al. $(2010,2011)$ recently suggested to explain the differences in both $\mathrm{pCO}_{2 \mathrm{~atm}}$ and $\delta^{13} \mathrm{C}$ between glacial and interglacial times as resulting from brine-induced ocean stratification in the Southern Ocean. Indeed, sea-ice formation around Antarctica releases salt, which induces the formation of very saline waters underneath. During interglacial times, most of this water mass would be mixed with freshwater from ice shelf melting; only a fraction would sink down the continental slope. During glacial times, the expansion of the Antarctic ice sheet, alongside lowering of the sea level, changes this configuration: most of the saline water mass would flow along the continental slope to reach the deep ocean (Bouttes et al. 2010). In addition to these changes, sea-ice formation is also enhanced during glacial times due to (1) enhanced katabatic winds along the ice sheet and (2) cooling of sea surface temperatures (SST). This enhanced sinking of brines may be responsible for transferring carbon in the deep ocean. Moreover, during the LGM, we know from salinity reconstructions thanks to pore fluid measurements (Adkins et al. 2002) and from $\delta^{13} \mathrm{C}$ data (Curry and Oppo 2005) that the deep and bottom water masses were saltier and that the ocean was more stratified than today. The sinking of brine mechanism, with enhanced top-to-bottom transport of dense waters, can partly explain both the high salinity and increased stratification. The deep glacial ocean reservoir would then be carbon-enriched but also ${ }^{14} \mathrm{C}$-depleted because this water mass would be well isolated from the upper ocean caused by intensified stratification.

Numerous studies measure evidence of such an isolated deep reservoir in the ocean (Sikes et al. 2000; Skinner et al. 2010; Thornalley et al. 2011; Burke and Robinson 2012). Other studies, however, question the existence of such a ${ }^{14} \mathrm{C}$-depleted deep ocean carbon reservoir mainly because of the lack of low ${ }^{14} \mathrm{C}$ concentrations in their measurements (Broecker and Clark 2010; De Pol-Holz et al. 2010; Cléroux et al. 2011) or because of the potential dissipation of such a signal induced in the ocean (Hain et al. 2011). Some others at least question its Southern Ocean origin: the deep reservoir alimentation could come from the North Pacific water masses (Rose et al. 2010) or from the North Atlantic-ventilated water masses (Kwon et al. 2012).

We show here that (1) a deep ${ }^{14} \mathrm{C}$-depleted and $\mathrm{CO}_{2}$-enriched ocean reservoir mainly due to brineinduced ocean stratification in the Southern Ocean is plausible to explain $\mathrm{LGM}$ values of $\Delta^{14} \mathrm{C}$, $\delta^{13} \mathrm{C}$, and $\mathrm{pCO}_{2 \text { atm }}$ and that (2) this is the main mechanism responsible for changes in ${ }^{12} \mathrm{C},{ }^{13} \mathrm{C}$, and ${ }^{14} \mathrm{C}$ over the last deglaciation in our modeling experiment.

\section{MODEL AND EXPERIMENTAL DESIGN}

\section{Model Developments}

CLIMBER-2 (Petoukhov et al. 2000) is a climate model of intermediate complexity that includes full carbon cycling (both in land and ocean), and computes explicitly carbon isotopes ${ }^{13} \mathrm{C}$ and ${ }^{14} \mathrm{C}$ (Brovkin et al. 2002, 2007). It has already been successfully tested under glacial conditions (Ganopolski and Rahmstorf 2001). For the specific needs of our study, we have further developed this model. Previously, $\Delta^{14} \mathrm{C}_{\text {atm }}$ was set to a constant level. It is now interactively computed by the model with explicit fluxes from the ocean and the terrestrial biosphere. Following Tschumi et al. (2011), we do not apply any isotopic fractionation on ${ }^{14} \mathrm{C}$ (neither biological nor air-sea exchanges), and thus can compare directly to the $\Delta^{14} \mathrm{C}$ from the data.

\section{Forcings and Varying Parameters}

In order to obtain $\Delta^{14} \mathrm{C}_{\text {atm }}=0 \%$ in preindustrial times (PI), we have adjusted the cosmogenic production rate from Masarik and Beer (1999) (2.02 atom cm $\left.\mathrm{cm}^{-2} \mathrm{~s}^{-1}( \pm 10 \%)\right)$ to the carbon budget of CLIMBER-2. All our glacial simulations are under LGM boundary conditions, with glacial solar 
insolation from Berger (1978) and ice sheets from Peltier (2004). The salinity and nutrient mean concentrations are increased by $3.3 \%$ to account for the $\sim 120$-m sea-level fall. $\mathrm{pCO}_{2 \mathrm{~atm}}$ is explicitly simulated in our model, thus responding to changes in land and ocean reservoirs to climate change. However, the radiative effect of $\mathrm{pCO}_{2 \mathrm{~atm}}$ is computed with a constant $\mathrm{pCO}_{2 \mathrm{~atm}}$ value of $190 \mathrm{ppm}$ (Monnin et al. 2001), and not varying in time for our LGM simulations. In the following, we only show the varying $\mathrm{pCO}_{2 \mathrm{~atm}}$.

Following the study of Bouttes et al. (2011), which successfully reconciled $\mathrm{LGM} \mathrm{pCO}$ and $\delta^{13} \mathrm{C}$, we have studied different model settings by changing the values of key parameters for the mechanisms considered here. In addition to varying the sinking of brines, we also consider the following potential mechanisms: iron fertilization that can increase the uptake of carbon by biology; and the sensitivity of vertical diffusion to brine-induced stratification that isolates deep waters from surface waters. The values of these parameters are listed in Table 1.

Table 1 Parameter values in the different simulations: frac is the fraction of salt released by sea-ice formation that sinks to the bottom of the ocean; alpha measures the sensitivity of vertical diffusion to stratification through the formula $\mathrm{K}_{\mathrm{z}}=\mathrm{K}_{0}\left(\frac{N}{N_{0}}\right)^{-\alpha}$ where $N=\left(\frac{g}{\rho_{0}} \frac{\partial_{\rho}}{\partial_{z}}\right)^{1 / 2}$; iron measures the proportion of nutrients consumed for photosynthesis and can vary between 0 (no nutrient consumed) and 1 (all nutrients consumed, equivalent to a maximum iron fertilization); prodC14 is normalized by the preindustrial production rate, which means that preindustrial prodC14 would be equal to 1 . The range of the parameter values is chosen after the study of Bouttes et al. (2011).

\begin{tabular}{lllll}
\hline Parameters & frac & alpha & iron & prodC14 \\
\hline PI simulation & 0 & 0 & 0 & 1 \\
LGM runs - 1st set & $0.6 ; 0.7 ; 0.8$ & $0.5 ; 0.6 ; 0.7 ; 0.8$ & $0.0 ; 0.1 ; 0.2 ; 0.3$ & 1 \\
LGM runs - 2nd set & $0.6 ; 0.7 ; 0.8$ & $0.5 ; 0.6 ; 0.7 ; 0.8$ & $0.0 ; 0.1$ & $1.15 ; 1.20 ; 1.25 ; 1.30$ \\
LGM best guess & 0.8 & 0.5 & 0.1 & 1.25 \\
\hline
\end{tabular}

\section{Towards a Best-Guess Simulation}

We performed 2 sets of experiments (see Table 1). For the first set, we kept the ${ }^{14} \mathrm{C}$ production rate at its preindustrial value, and looked for simulations where $\mathrm{pCO}_{2 \mathrm{~atm}}, \delta^{13} \mathrm{C}_{\mathrm{atm}}$ and Atlantic $\Delta \delta^{13} \mathrm{C}_{\text {ocn }}$ were in the LGM data range (185 to $195 \mathrm{ppm}$ for $\mathrm{pCO}_{2},-6.55$ to $-6.35 \%$ for $\delta^{13} \mathrm{C}_{\text {atm }}$, and $1.3-1.5 \%$ for Atlantic $\Delta \delta^{13} \mathrm{C}_{\text {ocn }}\left(\delta^{13} \mathrm{C}\right.$ gradient in the Atlantic between the surface [0-2000 $\left.\mathrm{m}\right]$ and the bottom [3000-5000 m]). In the second set of experiments, we kept the parameters corresponding to the 7 simulations that were in the $\mathrm{LGM} \mathrm{pCO}{ }_{2 \mathrm{~atm}}$ and $\delta^{13} \mathrm{C}$ data range, and we changed the ${ }^{14} \mathrm{C}$ production rate within the range of LGM production data (1.15 to 1.4, Laj et al. 2002). The objective was to simulate the LGM $\Delta^{14} \mathrm{C}_{\text {atm }}$ in the range of the data (between 330 and $500 \%$ ). At that point, we selected a "best guess" simulation, which is the simulation that minimizes the distance between LGM data and simulated $\Delta{ }^{14} \mathrm{C}_{\mathrm{ocn}}$. The $\mathrm{pCO}_{2 \mathrm{~atm}}, \delta^{13} \mathrm{C}$, and $\Delta{ }^{14} \mathrm{C}$ values of the best guess are therefore all in the range of data. Note that the ${ }^{14} \mathrm{C}$ production rate is set to a constant value in our simulations. We have indeed assumed that the time variation of the production prior to the LGM was negligible in explaining LGM $\Delta{ }^{14} \mathrm{C}_{\text {atm }}$, which seems reasonable, because according to Laj et al. (2002), the ${ }^{14} \mathrm{C}$ production rate varied only between 1.05 and 1.40 in the $10 \mathrm{kyr}$ preceding the LGM (compared to the $0.75-2.20$ range during the last $75 \mathrm{kyr}$ ). The effect of time variations of ${ }^{14} \mathrm{C}$ production will be tested in future studies.

In the following, we discuss this best-guess simulation, along with its decomposition in the different mechanisms involved, to evaluate the relative part of each of these mechanisms in explaining changes in $\Delta{ }^{14} \mathrm{C}_{\text {atm }}$ and $\mathrm{pCO}_{2 \mathrm{~atm}}$. 


\section{$V$ Mariotti et al.}

\section{RESULTS AND DISCUSSION}

Before conducting the LGM simulations, we address the performance of the simulated ${ }^{14} \mathrm{C}$ data in the new version of CLIMBER-2 compared to the prebomb GLODAP (Key et al. 2004) data (Figure 1). We performed a simulation under preindustrial and prebomb conditions, with atmospheric $\Delta^{14} \mathrm{C}$ set at $0 \%$. For the Atlantic section, our simulation results are very close to both the mean value and the distribution of $\Delta^{14} \mathrm{C}$ concentrations, even if the model tends to be slightly more stratified as shown by the too-negative values of $\Delta^{14} \mathrm{C}(-150 \%$ vs. $-110 \%$ in GLODAP) in the deep South Atlantic. For the Pacific section, the Southern Ocean part is well represented, but the deep North Pacific Ocean has too-low $\Delta^{14} \mathrm{C}$ concentrations (-300\%o vs. $-220 \%$ in GLODAP), which are due to the misrepresentation of deep Pacific water masses characteristics, an outcome of the longitudinally averaged basins configuration of the CLIMBER-2 ocean model. Nonetheless, even in more complex 3D ocean general circulation models, very negative values of $\Delta^{14} \mathrm{C}$ are often simulated in the deep North Pacific ocean (Orr 2004; Franke et al. 2008; Tschumi et al. 2011). Overall, the simulated $\Delta^{14} \mathrm{C}$ values agree with the data in most of the ocean, especially in the Atlantic Ocean and the Southern Ocean, which are crucial basins for the sinking of brine mechanism we are testing here.

a) Atlantic GLODAP zonal mean

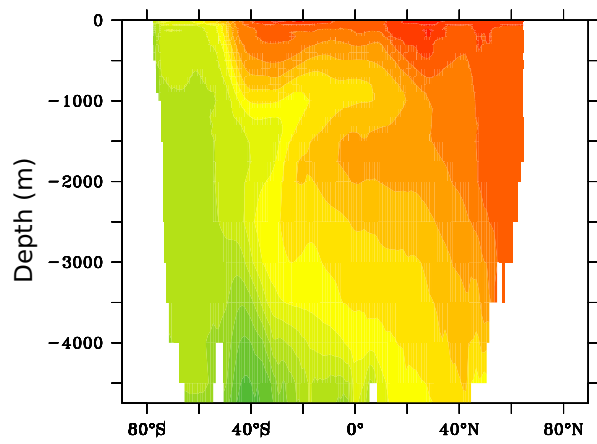

c) Pacific GLODAP zonal mean

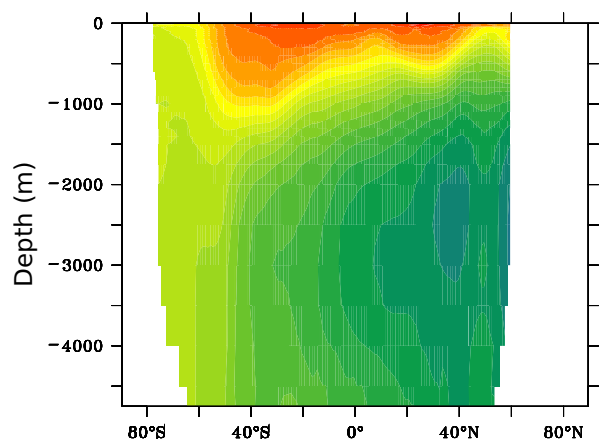

b) Atlantic model section

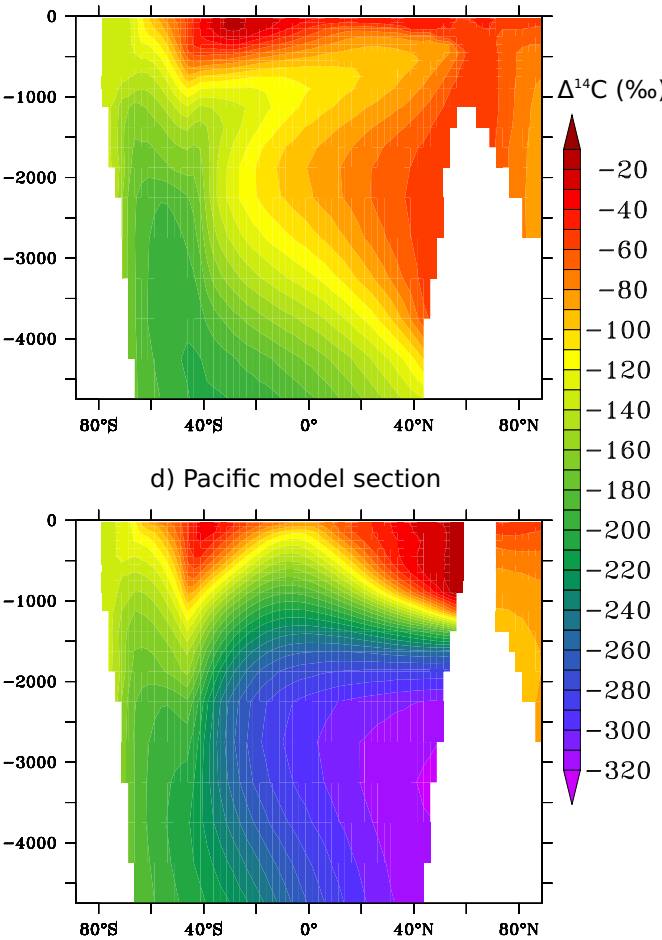

Figure 1 Comparison of GLODAP prebomb $\Delta^{14} \mathrm{C}$ concentrations (Key et al. 2004) averaged for each basin (a) Atlantic and c) Pacific), and CLIMBER-2 preindustrial simulation sections (b) Atlantic and d) Pacific).

The best guess for LGM simulations is obtained for high values of frac and alpha ( 0.8 and 0.5 respectively, see Table 1) and for a rather small value of iron (0.1). Thus, the brine mechanism (sinking of brines and brine-induced stratification effect on vertical mixing) seems to be more important than the biological pump in explaining changes in the carbon cycle for the last deglaciation. The 
change in production rate is also significant ( $\operatorname{rrodC} 14=1.25$, i.e. $25 \%$ more than under preindustrial conditions), but this is still within the average of LGM estimates (Laj et al. 2002). It is thus not necessary to increase the cosmogenic production beyond 1.4 to have ${ }^{14} \mathrm{C}$ results in agreement with LGM data. The values obtained for the different carbon constraints are within the LGM data error bars: $\Delta{ }^{14} \mathrm{C}_{\text {atm }}=447 \%$; $\mathrm{pCO}_{2 \mathrm{~atm}}=191.5 \mathrm{ppm} ; \delta^{13} \mathrm{C}_{\mathrm{atm}}=-6.36 \%$; and $\Delta \delta^{13} \mathrm{C}_{\mathrm{ocn}}=1.3 \%$.
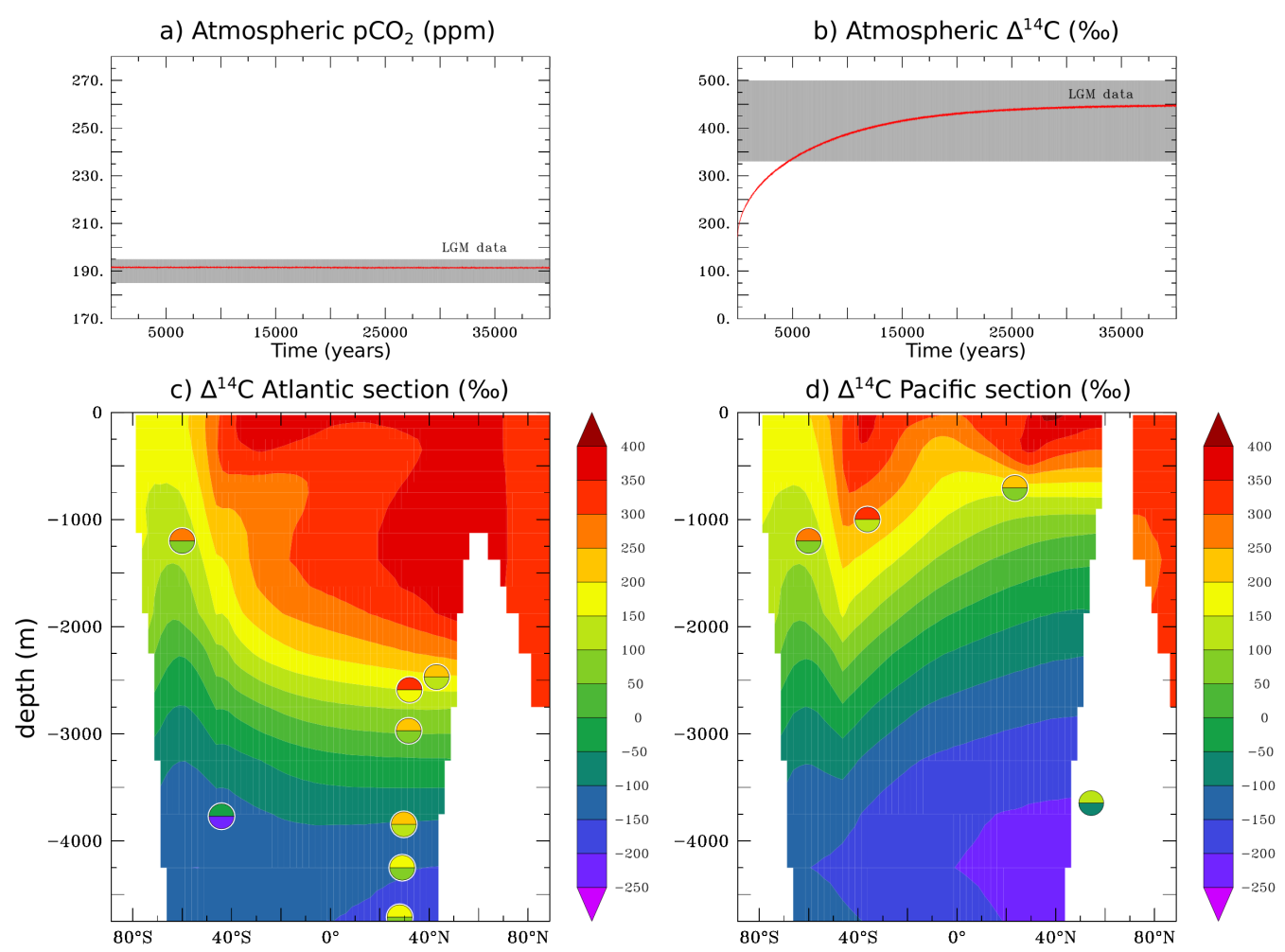

Figure 2 Best-guess results (defined in Figure 3): a) Atmospheric $\mathrm{pCO}_{2}$ as a function of model time (yr); b) Atmospheric $\Delta^{14} \mathrm{C}(\%)$; Sections of $\Delta^{14} \mathrm{C}(\%)$ in c) the Atlantic Ocean and d) the Pacific Ocean. In the last 2 plots, the fields represent the simulated year 40,000 and data points incorporate the error bar inherent to the data: the upper (respectively lower) part of the circle represents the maximum (respectively minimum) value of $\Delta^{14} \mathrm{C}$ in the core at the dated LGM section. Data references are Burke and Robinson (2012); De Pol-Holz et al. (2010); Galbraith et al. (2007); Keigwin (2004); Marchitto et al. (2007); Robinson et al. (2005); and Skinner et al. (2010).

If we consider the $\Delta^{14} \mathrm{C}_{\text {ocn }}$ results of the best guess, we can see in Figure 2 that the model fits all the reconstructions that are located within the model ocean boundaries, except for 3 . Those reconstructions are all located below $3500 \mathrm{~m}$ in the North Atlantic Ocean, in the western part (Keigwin 2004), and might thus capture the young water masses coming from the lower branch of the thermohaline circulation. We only have a longitudinally averaged ocean in CLIMBER-2, which cannot capture such circulation pathways. Moreover, we have seen that in the modern simulation, the deep North Atlantic (below $3500 \mathrm{~m}$ ) is already too old compared to GLODAP data. The same problem arises for the reconstruction located in the deep North Pacific: by extrapolation we see that the model is too old compared to this data, and this area is already too old in the modern simulation. These results highlight the limits of the CLIMBER-2 model as we clearly need a 3D ocean model to correctly represent circulation in the deep North Atlantic and Pacific. Nonetheless, despite the longitudinally 


\section{VMariotti et al.}

averaged ocean basins, the CLIMBER-2 model simulates results that are within the LGM $\Delta^{14} \mathrm{C}_{\mathrm{ocn}}$ error bar for $64 \%$ of the data points ( 7 out of 11 ), which demonstrates some general agreement with the data.

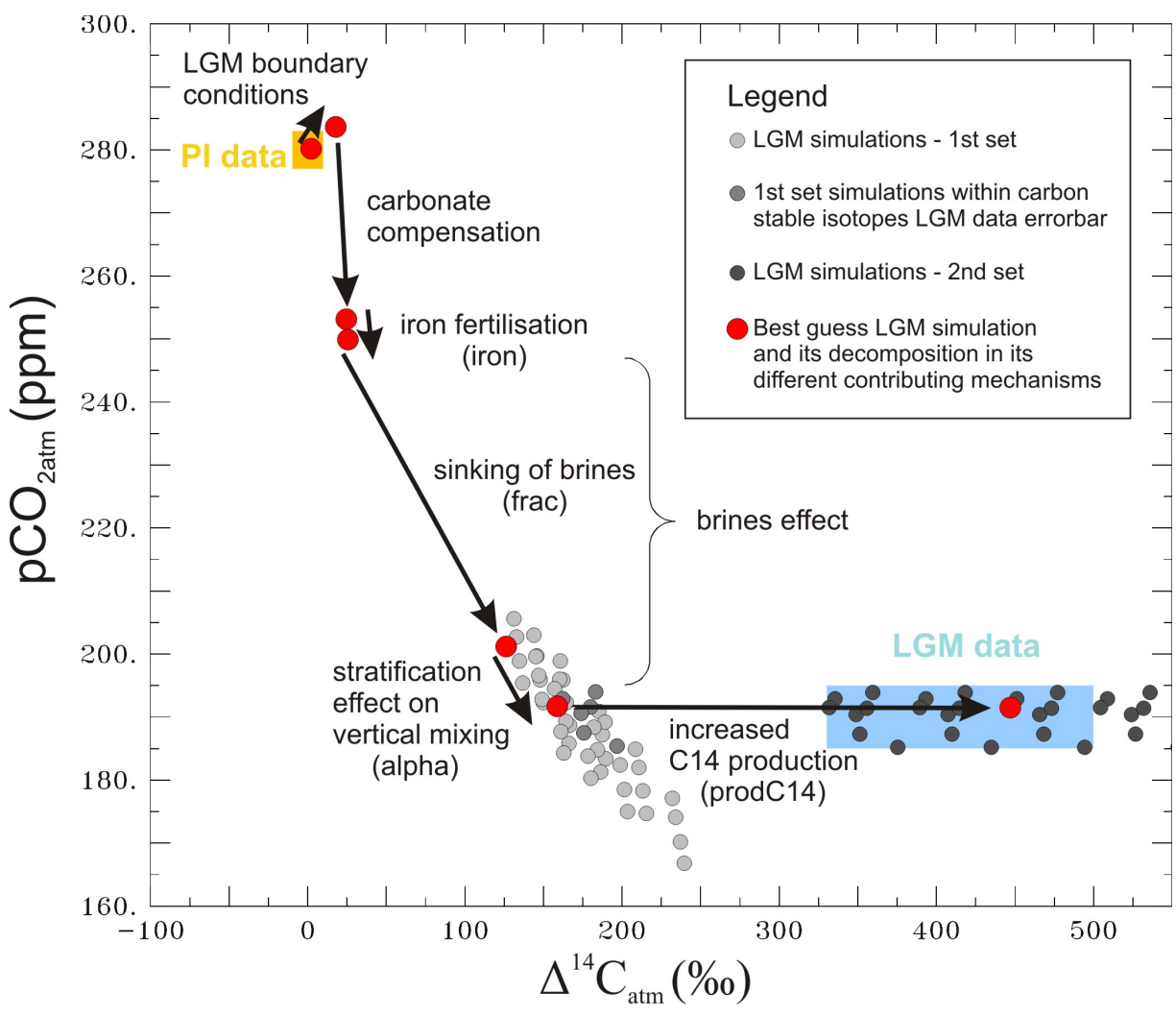

Figure 3 Summary of all the simulations performed and decomposition of the best-guess simulation in the different mechanisms involved. $\mathrm{pCO}_{2 \mathrm{~atm}}$ is represented as a function of $\Delta \Delta^{14} \mathrm{C}_{\mathrm{atm}}$. The different circle colors are explained in the legend box.

We have decomposed the best guess in each of the mechanisms involved in the glacial-interglacial differences to have an estimate of their relative importance (Figure 3). This decomposition is only a first-order estimate, as the different mechanisms presented are non-linear (e.g. enhanced ${ }^{14} \mathrm{C}$ production more strongly affects the atmosphere when the ocean takes up less carbon). As expected from the parameter values, the iron fertilization does not have a significant impact on $\mathrm{pCO}_{2 \mathrm{~atm}}(-3 \mathrm{ppm})$ nor on $\Delta^{14} \mathrm{C}_{\mathrm{atm}}(+1 \%)$. Carbonate compensation only impacts the $\mathrm{pCO}_{2 \mathrm{~atm}}(34 \%$ or $-30 \mathrm{ppm})$, not $\Delta \Delta^{14} \mathrm{C}_{\mathrm{atm}}(2 \%$ or $+7 \%$ ). The brine mechanism (sinking of brines and stratification effect on vertical mixing) has an important impact on both $\mathrm{pCO}_{2 \text { atm }}(66 \%$ or $-72 \mathrm{ppm})$ and $\Delta^{14} \mathrm{C}_{\text {atm }}(30 \%$ or $+133 \%$ o and $85 \%$ of the part of $\Delta^{14} \mathrm{C}_{\text {atm }}$ not related to the cosmogenic production, prodC14). It is worth noting that in our simulations, the brine mechanism, which implies the existence of an old deep ocean carbon reservoir, is necessary to simulate the $\mathrm{pCO}_{2 \mathrm{~atm}}$ and $\Delta{ }^{14} \mathrm{C}_{\mathrm{atm}}$ values within the range of the data, so our study supports the existence of such a reservoir.

More importantly, the addition of LGM boundary conditions, carbonate compensation, iron fertilization, sinking of brines, increased stratification, and increased prodC14 allow us to reach the LGM 


\section{Simulated LGM $\Delta^{14} C_{a t m}$ and Deep Glacial Ocean C}

data range for $\mathrm{pCO}_{2}, \delta^{13} \mathrm{C}_{\mathrm{atm}}$, Atlantic $\Delta \delta^{13} \mathrm{C}_{\mathrm{ocn}}$, and $\Delta{ }^{14} \mathrm{C}_{\mathrm{atm}}$, which are the main carbon data constraints existing for that period.

In conclusion, when we take into account carbonate compensation, the sinking of brines mechanism, iron fertilization and stratification-dependent diffusion, not only are the $\mathrm{LGM} \mathrm{CO}_{2}$ and $\delta^{13} \mathrm{C}$ reconciled, but also the $\Delta^{14} \mathrm{C}$. This study also highlights the major role of the brine mechanism in setting the last deglaciation $\mathrm{CO}_{2}$ level $(66 \%)$ and $\Delta^{14} \mathrm{C}_{\text {atm }}$ changes $\left(85 \%\right.$, part of $\Delta{ }^{14} \mathrm{C}_{\text {atm }}$ not related to the cosmogenic production). Further simulations need to be done with an ocean general circulation model in order to test the processes involved in a more mechanistic way. Finally, this study is the first attempt to our knowledge of a model experiment to explain the glacial-interglacial differences in $\mathrm{pCO}_{2 \mathrm{~atm}}, \delta^{13} \mathrm{C}$, and $\Delta^{14} \mathrm{C}$ with a coherent LGM climate.

\section{ACKNOWLEDGMENTS}

We thank Elisabeth Michel, Claire Waelbroeck, and Fortunat Joos for their helpful discussion on $\Delta^{14} \mathrm{C}$ data and Jean-Claude Dutay and James Orr for their useful explanations on the Ocean Carbon Model Intercomparison Project OCMIP-II database.

\section{REFERENCES}

Adkins J, McIntyre K, Schrag DP. 2002. The salinity, temperature, and $\delta^{18} \mathrm{O}$ of the glacial deep ocean. Science 298(5599): 1769-73.

Berger A. 1978. Long-term variations of daily insolation and quaternary climatic changes. Journal of Atmospheric Sciences 35:2362-7.

Bouttes N, Paillard D, Roche DM. 2010. Impact of brineinduced stratification on the glacial carbon cycle. $\mathrm{Cli}$ mate of the Past 6:681-710.

Bouttes N, Paillard D, Roche D, Brovkin V, Bopp L. 2011. Last glacial maximum $\mathrm{CO}_{2}$ and $\delta^{13} \mathrm{C}$ successfully reconciled. Geophysical Research Letters 38: L02705, doi:10.1029/2010GL044499.

Broecker W, Barker S. 2007. A $190 \%$ drop in atmosphere's $\Delta{ }^{14} \mathrm{C}$ during the "Mystery Interval" (17.5 to $14.5 \mathrm{kyr}$ ). Earth and Planetary Science Letters 256(12):90-9.

Broecker W, Clark E. 2010. Search for a glacial-age ${ }^{14} \mathrm{C}$ depleted ocean reservoir. Geophysical Research Letters 37: L13606, doi:10.1029/2010GL043969.

Brovkin V, Bendtsen J, Claussen M, Ganopolski A, Kubatzki C, Petoukhov V, Andreev A. 2002. Carbon cycle, vegetation, and climate dynamics in the Holocene: experiments with the CLIMBER-2 model. Global Biogeochemical Cycles 16(4):1139, doi: 10.1029/2001GB001662.

Brovkin V, Ganopolski A, Archer D, Rahmstorf S. 2007. Lowering of glacial atmospheric $\mathrm{CO}_{2}$ in response to changes in oceanic circulation and marine biogeochemistry. Paleoceanography 22: PA4202, doi: 10.1029/2006PA001380.

Burke A, Robinson L. 2012. The Southern Ocean's role in carbon exchange during the last deglaciation. Science 335(6068):557-61.

Cléroux C, deMenocal P, Guilderson T. 2011. Deglacial radiocarbon history of tropical Atlantic thermocline waters: absence of $\mathrm{CO}_{2}$ reservoir purging signal. Quaternary Science Reviews 30(15-16):1875-82.

Curry WB, Oppo DW. 2005. Glacial water mass geometry and the distribution of $\delta^{13} \mathrm{C}$ of $\Sigma \mathrm{CO}_{2}$ in the western Atlantic Ocean. Paleoceanography 20: PA1017, doi: 10.1029/2004PA001021.

De Pol-Holz R, Keigwin L, Southon J, Hebbeln D, Mohtadi M. 2010. No signature of abyssal carbon in intermediate waters off Chile during deglaciation. $\mathrm{Na}$ ture Geoscience 3:192-5.

Franke J, Paul A, Schulz M. 2008. Modeling variations of marine reservoir ages during the last 45000 years. Climate of the Past Discussions 4:81-110.

Galbraith E, Jaccard S, Pedersen T, Sigman D, Haug G, Cook M, Southon J, Francois R. 2007. Carbon dioxide release from the North Pacific abyss during the last deglaciation. Nature 449(7164):890-3.

Ganopolski A, Rahmstorf S. 2001. Rapid changes of glacial climate simulated in a coupled climate model. $\mathrm{Na}$ ture 409(6817): 153-8.

Hain MP, Sigman DM, Haug GH. 2011. Short-comings of the isolated abyssal reservoir model for deglacial radiocarbon changes in the mid-depth Indo-Pacific Ocean. Geophysical Research Letters 38: L04604, doi:10.1029/2010GL046158.

Keigwin L. 2004. Radiocarbon and stable isotope constraints on Last Glacial Maximum and Younger Dryas ventilation in the western North Atlantic. Paleoceanography 19: PA4012, doi:10.1029/2004PA001029.

Key RM, Kozyr A, Sabine CL, Lee K, Wanninkhof R, Bullister JL, Feely RA, Millero FJ, Mordy C, Peng TH. 2004. A global ocean carbon climatology: results from global data analysis project (GLODAP). Global Biogeochemical Cycles 18: GB4031. 


\section{Mariotti et al.}

Köhler P, Fischer H, Munhoven G, Zeebe R. 2005. Quantitative interpretation of atmospheric carbon records over the last glacial termination. Global Biogeochemical Cycles 19: GB4031, doi:10.1029/ 2004GB002247.

Köhler P, Muscheler R, Fischer H. 2006. A model-based interpretation of low frequency changes in the carbon cycle during the last 120,000 years and its implications for the reconstruction of atmospheric $\Delta^{14} \mathrm{C}$. Geochemistry, Geophysics, Geosystems 7: Q11N06, doi:10.1029/2005GC001228.

Kwon EY, Hain MP, Sigman DM, Galbraith ED, Sarmiento JL, Toggweiler JR. 2012. North Atlantic ventilation of "southern-sourced" deep water in the glacial ocean. Paleoceanography 27: PA2208, doi: 10.1029/2011PA002211.

Laj C, Kissel C, Mazaud A, Michel E, Muscheler R, Beer J. 2002. Geomagnetic field intensity, North Atlantic Deep Water circulation and atmospheric $\Delta^{14} \mathrm{C}$ during the last 50 kyr. Earth and Planetary Science Letters 200(1-2):177-90.

Marchitto TM, Lehman SJ, Ortiz JD, Flückiger J, van Geen A. 2007. Marine radiocarbon evidence for the mechanism of deglacial atmospheric $\mathrm{CO}_{2}$ rise. Science 316(5830):1456-9.

Masarik J, Beer J. 1999. Simulation of particle fluxes and cosmogenic nuclide production in the Earth's atmosphere. Journal of Geophysical Research 104(D10): 12,099-11.

Meissner K, Schmittner A, Weaver A, Adkins J. 2003. Ventilation of the North Atlantic Ocean during the last glacial maximum: a comparison between simulated and observed radiocarbon ages. Paleoceanography 18:1023, doi:10.1029/2002PA000762.

Mix AC, Bard E, Schneider R. 2001. Environmental processes of the ice age: land, oceans, glaciers (EPILOG). Quaternary Science Reviews 20(4):627-57.

Monnin E, Indermühle A, Dällenbach A, Flückiger J, Stauffer B, Stocker TF, Raynaud D, Barnola J-M. 2001. Atmospheric $\mathrm{CO}_{2}$ concentrations over the last glacial termination. Science 291(5501):112-4.

Muscheler R, Beer J, Wagner G, Laj C, Kissel C, Raisbeck GM, Yiou F, Kubik PW. 2004. Changes in the carbon cycle during the last deglaciation as indicated by the comparison of ${ }^{10} \mathrm{Be}$ and ${ }^{14} \mathrm{C}$ records. Earth and Planetary Science Letters 219(3-4):325-40.

Muscheler R, Beer J, Kubik P, Synal H. 2005. Geomagnetic field intensity during the last 60,000 years based on ${ }^{10} \mathrm{Be}$ and ${ }^{36} \mathrm{Cl}$ from the summit ice cores and ${ }^{14} \mathrm{C}$. Quaternary Science Reviews 24(16-17):1849-60.

Orr JC. 2004. Modelling of ocean storage of $\mathrm{CO}_{2}$ - the GOSAC study. IEA Greenhouse Gas R\&D Programme Report PH4/37. 96 p. International Energy Agency.

Peltier W. 2004. Global glacial isostasy and the surface of the ice-age Earth: the ICE-5G (VM2) model and GRACE. Annual Review of Earth and Planetary Sciences 32:111-49.

Petoukhov V, Ganopolski A, Brovkin V, Claussen M, Eliseev A, Kubatzki C, Rahmstorf S. 2000. CLIMBER2: a climate system model of intermediate complexity. Part I: model description and performance for present climate. Climate Dynamics 16(1):1-17.

Reimer PJ, Baillie MGL, Bard E, Bayliss A, Beck JW, Blackwell PG, Bronk Ramsey C, Buck CE, Burr GS, Edwards RL, Friedrich M, Grootes PM, Guilderson TP, Hajdas I, Heaton T, Hogg AG, Hughen KA, Kaiser KF, Kromer B, McCormac FG, Manning SW, Reimer RW, Richards DA, Southon JR, Talamo S, Turney CSM, van der Plicht J, Weyhenmeyer CE. 2009. IntCa109 and Marine09 radiocarbon age calibration curves, 0-50,000 years cal BP. Radiocarbon 51(4): $1111-50$.

Robinson LF, Adkins JF, Keigwin LD, Southon J, Fernandez DP, Wang S-L, Scheirer DS. 2005. Radiocarbon variability in the western North Atlantic during the last deglaciation. Science 310(5753):1469-73.

Rose KA, Sikes EL, Guilderson TP, Shane P, Hill TM, Zahn R, Spero HJ. 2010. Upper-ocean-to-atmosphere radiocarbon offsets imply fast deglacial carbon dioxide release. Nature 466(7310):1093-7.

Sikes E, Samson C, Guilderson T, Howard W. 2000. Old radiocarbon ages in the southwest Pacific Ocean during the last glacial period and deglaciation. Nature 405(6786):555-9.

Skinner LC, Fallon S, Waelbroeck C, Michel E, Barker S. 2010. Ventilation of the deep Southern Ocean and deglacial $\mathrm{CO}_{2}$ rise. Science 328(5982):1147-51.

Thornalley DJR, Barker S, Broecker WS, Elderfield H, McCave IN. 2011. The deglacial evolution of North Atlantic deep convection. Science 331(6014):202-5.

Tschumi T, Joos F, Gehlen M, Heinze C. 2011. Deep ocean ventilation, carbon isotopes, marine sedimentation and the deglacial $\mathrm{CO}_{2}$ rise. Climate of the Past 7 : 771-800. 